Article received on May $11^{\text {th }} 2020$

Article accepted on June $5^{\text {th }} 2020$

Original scientific paper

UDC 78.071.5 Микић B.

\begin{abstract}
Adriana Sabo*
Junior Researcher, $\mathrm{PhD}$ Candidate

Department of Musicology, Faculty of Music

University of Arts in Belgrade
\end{abstract}

\title{
PEDAGOGICAL WORK OF VESNA MIKIĆ
}

\begin{abstract}
This paper focuses on the teaching work of Vesna Mikić, PhD (1967-2019), full professor at the Department of Musicology of the Faculty of Music in Belgrade. Considering that she was tied to this institution throughout most of her professional career, the paper will offer an outlook on the curricula of the subjects which she taught over the years, and an attempt to shed light on her approach to teaching and to the subject matter she taught. In addition, the paper will focus on her work as a mentor, and attempt to pinpoint a number of aspects that connected her work as a scholar, pedagogue and mentor.
\end{abstract}

Keywords: Vesna Mikić, musicology, Faculty of Music, education, music history, popular music, electroacoustic music

When viewing the professional activities of Vesna Mikić (1967-2019) in musicology, it is clear that they were divided into two main complementary flows - scholarly and educational. As can be expected, she had been active in both areas because of her position in the Department of Musicology at the Faculty of Music in Belgrade. This paper will focus on the former - especially due to the fact that working with young generations of students grew ever more important as her career progressed. The institutional position she held - which implied musicological research, as well as a form of care for the future of musicology through working with students and future researchers - enabled her to form a unique professional position, one which was deeply

\footnotetext{
* The author's contact details: adrianasabo259@gmail.com
} 
defined precisely by her work with young musicologists and musicians. Bearing that in mind, in the lines that follow, I will offer an outlook on some of the subjects she taught, the structure of the curricula, and stress the importance of her work as a professor in the local musical community, as well as among her students.

Even though the main part of her career as a professor was tied to the Faculty of Music, ${ }^{1}$ Professor Mikić taught, at different times, at the Faculty of Arts in Priština, the Faculty of Music in Cetinje, the Faculty of Philology and Arts in Kragujevac, the Academy of Arts in Novi Sad, and taught a number of subjects which were part of Interdisciplinary Studies at the University of Arts in Belgrade (departments for the Theory of Arts and Media, for Digital Art and for Polymedia Art), as well as at the Academy of Arts of the University in Banja Luka. The main focus of the subjects she taught was on the artistic music of the $20^{\text {th }}$ and $21^{\text {st }}$ centuries (with special emphasis on the music of Yugoslavia and on neoclassicism), as well as popular, electroacoustic, film and television music - music defined by its relation with the media and, in different ways, by technology and/or the entertainment/music industry. Other than being one of the professors who regularly 'stepped out' of the boundaries of classical music, many will remember her as a warm and cordial person who was open and sincere in her communication with colleagues and students, as well as for her seemingly inexhaustible energy and lively lectures.

As I already mentioned, an important segment of her lectures pertained to the area of the history of local and European classical music of the $20^{\text {th }}$ century, which she taught to fourth-year students of musicology, as well as to students of other departments at the Faculty. A very important feature of Professor Mikićs lecturing style and of the way in which she envisioned the subjects, was the understanding of music within the historical and political context, and insisting on the fact that music is a social phenomenon, related to political, economic and ideological changes. Thus, her lectures always took into account the political aspects of (classical) music, understanding of the world of music in light of the turbulent social developments that had marked Europe's history. Just like her musicological research, the lectures were always inter-, as well as transdisciplinary, ${ }^{2}$ with - of course - her focus always re-

1 She started working at the institution in 1992, as an assistant professor, and in 2015, she became a full professor.

2 Speaking of the importance of such an understanding of music, Vesna Mikić states that a form of 'postmodernist intensification of musicology in context' proved to be crucial 
maining firmly on music in the field and its features. In her lectures, Professor Mikić attempted to always make her students aware of the reasons why we learn (musical) history, pointing to the fact that understanding history enables us to understand our contemporary situation. In that sense, in her lectures in music history, she always emphasised its usefulness to different musical professions - helping players, conductors and composers to better understand the music they were performing or creating, as well as to understand their own artistic position and poetics, and helping students of musicology, ethnomusicology and music theory to formulate and understand their own theoretical positions and agendas. By always emphasising the fact that we are all parts of Serbia's world of music, as well as of our society as a whole, she was adamant in getting her students to develop their own opinions and professional agendas, and to stand behind their opinions and views.

Other than through lectures and research dedicated to works and artists that belong to the canon of classical music, Prof. Vesna Mikić also worked tirelessly on promoting and explaining those kinds of music that are usually perceived as being 'outside' of the canon. Thus, she offered electoral subjects that focused on popular music (Theories of Popular Culture and Arts /2005/, Popular Music 1 - Theories /2009/ and Popular Music 2 - Genres /2012/, and History of Popular Music 1 and $2 / 2016 /$ ), electroacoustic and film music. Due to the fact that, in her musicological work, Vesna Mikić was dedicated to critically viewing and questioning the boundaries of musicological discourse, she constantly strived to broaden its field of inquiry towards areas that were not the subject of interest of 'traditional' musicology. We could say that Professor Mikić was mainly interested in (as the title of the $\mathrm{PhD}$ thesis states ${ }^{3}$ ), music within (our) contemporary technoculture, that is, in different appearances that music has had in societies dominated by technology and media. In

for her pedagogical work as well. As she says, "For my pedagogical work that intensification was crucial. It enabled me, as a musicologist and teacher, not only to introduce and teach some new subjects [...] in the curricula of the faculty where I work, but also to teach and shape for almost a decade (till 2014) at the interdisciplinary postgraduate studies of the University of Arts, [...] non-musicological theoretical subjects derived from my doctoral thesis as the specific musicological appropriation of the concepts of cultural studies". Cf. Ivana Miladinović Prica, "Virtual Round-Table to Mark the 70th Anniversary of the Department of Musicology at The Faculty of Music in Belgrade (Vesna Mikić, Leon Stefanija, Ivana Perković, Dario Martinelli)", New Sound, 52, II/2018, 25.

3 Cf. Vesna Mikić, Muzika u tehnokulturi (Music in Technoculture), Belgrade, Univerzitet umetnosti (University of Arts), 2004. 
this sense, she contributed greatly to the institutionalisation of research into music which is not 'classical', or 'artistic' in the strict sense of the word, within the discipline of musicology. Even though electroacoustic music is, of course, part of the curriculum of subjects dedicated to the $20^{\text {th }}$ century music, it is important to stress that the electoral subject called 'Electroacoustic Music', offered students the possibility to focus in more detail, on music which is not composed and/or performed on traditional instruments, to view how technology influences music and, potentially, to direct their research to the field of electroacoustic music studies. Therefore, this course offered the students a body of knowledge about technology itself, instruments and devices used in composition - synthesizers, computers, software, etc. - as well as with procedures and ways in which they are used in music (with emphasis on analogue and digital technology, the process of synthesis, use of effects, filters, etc.). In other words, this course enabled the students to have a glimpse of the world of engineering, which is often considered foreign to musicians and artists.

In a similar way, Professor Mikić 'opened' her discourse towards researching popular music and culture, as well as the music industry and, subsequently, politics, the economy, etc. Even though popular music studies are a well-established field of research, which connects researchers from disciplines which are akin to musicology (sociology, cultural studies, media studies, etc.), research in this area from a musicological point of view was not very abundant in the local context until a few decades ago. Thus, one of the key contributions to the process of legitimisation and institutionalisation of popular music studies within musicology, came in the form of subjects dedicated precisely to these studies, subjects which were elected by numerous students of musicology, as well as of other departments of the Faculty. Given that the understanding of popular music requires one to view it as a social activity, as well as be aware of the key position technology occupies within the processes of its production, dissemination and perception, subjects dedicated to the research of popular music enabled students to understand complex social, political and economic issues which are, only at a first glance, 'outside' of music. ${ }^{4}$

${ }^{4}$ Besides continually working on creating courses for students at universities, Vesna Mikić also gave a number of open lectures, intended for students (of course), music teachers, as well as the general public. For instance, she was part of the seminar "Popular Music as an Integral Part of Contemporary Culture" (2013), organised by the Faculty of Music in Belgrade and the Composers' Association of Serbia (as part of the TEMPUS project). Cf. Udruženje kompozitora Srbije, Seminar o popularnoj muzici, 2013. http:// 
Her intention to institutionalise popular music studies within the musicological discourse also resulted in the founding of the Centre for Popular Music Research, ${ }^{5}$ the collaborators of which were mainly her (former) students, interested in researching popular music. ${ }^{6}$ Through the activities of the centre, she intended to provide the younger generations of artists and researchers with the opportunity to conduct their own research that would later be published and promoted in different ways.

The ever-changing, provocative questions of relationships between music and politics, technology and media, were presented within the course "Insieme - Unite, Unite Europe!' - Introduction to the Eurovision Song Contest Studies", which was, during the period from 2014 to 2017, part of the Jean Monnet module Musical Identities and European Perspective: an Interdisciplinary Approach. ${ }^{7}$ The course used as the starting point, "the assumption that the history of the united Europe, could not only be read from its annual song contest, but also seen as constitutive for the EU", and offered a reading of the ESC "from a predominantly musicological perspective". ${ }^{8}$ During the course of a number of lectures, Professor Mikić intended "students (to) achieve the skills in interpreting and analyzing this particular cultural phenomenon in a wider scope of European studies". ${ }^{9}$ In other words, this course offered students the opportunity to learn how to understand very complex issues, which are not 'only' musical, and to acquire knowledge about media, technology, politics, identity and, of course, music. With a similar intention, to formulate a musicological discourse that would enable the understanding of phenomena that are not 'purely musical', she created a course with Biljana Leković,

composers.rs/?p=3107. In addition, she gave a lecture at the Institute for Musicology of the Humboldt University in Berlin (in 2012), titled "Serbia Sounds European/Yugoslav/ Balkan/Global?: Popular music practices in an ever-transitional society", as well as two lectures for master students of Musicology at the Universty in Ljubljana: "Popular Music and Musicology - Interpretative Framework" и "Production, Technology, Music Industries - Case Study: Covers".

5 Website of the Center for Popular Music Research: http://www.cepom.org/ (website in Serbian).

${ }^{6}$ Collaborators of the Center: http://www.cepom.org/saradnici.html (in Serbian).

7 Jean Monnet Module "Musical Identities and European Perspective: An Interdisciplinary Approach", https://www.midep.ac.rs/

8 Vesna Mikić, “Insieme - Unite, Unite Europe!": Introduction to the Eurovision Song Contest Studies, http://www.midep.ac.rs/?page_id=317

9 Ibid. 
$\mathrm{PhD}$, which was part of the second Jean Monnet module held at the Faculty of Music in Belgrade. ${ }^{10}$ The course was titled "Integrating Media, Integrating Europe: Contemporary Serbian Music and European (Media) Integrations", and aimed "to integrate the musicological interpretations of diverse contemporary music practices into the contemporary, integrated media dispositive". ${ }^{11}$ As the course description states, "applying the acquired knowledge in media theory, as well as in the European media policies and institutions (based in European integration politics), would lead students to becoming aware of the importance and function of music in the overall processes of (cultural) integration". ${ }^{2}$

Despite the fact that Vesna Mikić's work as a professor was predominantly tied to the Faculty of Music, she also played an important role within the program of Interdisciplinary Studies at the University of Arts in Belgrade. There, she created a number of subjects dedicated to the interdisciplinary research of music: "Theories of Popular Culture and Arts" (since 2003, offered to students of the Department for the Theory of Arts and Media), and "Art and Politics" (since 2010, offered to students of the Theory of Arts and Media and Polymedia Art). She also coordinated the course "New Art Theories/New Media" (since 2008, departments for the Theory of Arts and Media, for Digital Art, and for Polymedia Art). As is evident from the titles, these courses followed a similar pattern to those already mentioned in the text, viewing music and art as being inseparable from politics and society.

Upon viewing the structure of the subjects she taught - I refer, mainly, to the mentioned electoral subjects- and thanks to my own experience as a student of Prof. Mikić, I would like to stress another important feature of her approach to teaching. Namely, by focusing on contemporary musical practices and issues related to the place music occupies in the lives of people, she attempted to provide her students with different kinds of knowledge that would prepare them for what comes after university - navigating the job market and for 'real life'. By explaining how the production of music, as well as of knowledge about music work, and how the media define every aspect of our lives,

\footnotetext{
10 ARTE. Music and Art in the Shaping of the European Cultural Identity, http://arte. bg.ac.rs/

11 Vesna Mikić, Biljana Leković, “Integrating Media, Integrating Europe: Contemporary Serbian Music and European (Media) Integrations", http://arte.bg.ac.rs/wp-content/uploads/2018/10/ISPRAVKA-Vesna-i-Biljana-obav.-kurs-ENG.pdf

12 Ibid.
} 
as well as our research subject(s), she insisted on teaching her students the skills they can use on the job market and in their future artistic and business endeavors. ${ }^{13}$

Another important aspect of Vesna Mikićs work as a professor, comes in the form of mentorships of graduation, master and doctoral theses, and her career was marked by a great many students choosing her as their mentor. It is precisely her diverse interest in different aspects of music, as well as her sincere and direct communication with students that made her popular among students of musicology, and interdisciplinary studies. Under her mentorship, 21 candidates defended their graduation theses (19 at the Department of Musicology, Faculty of Music in Belgrade, and two at the Academy of Arts in Novi Sad, /see Table 2/), and 16 students defended their master's theses (among them, 2 were defended at the program of Interdisciplinary Studies of the University of Arts in Belgrade, /see Table 3/); three candidates defended their master's theses (Valentina Radoman, Asja Radonjić, Tijana Paunković, /see Table 1/), and seven students acquired PhD titles: Biljana Leković and Milan Milojković, at the Department of Musicology, Iva Simčić, Smiljka Jovanović, Jelena Mihajlović Marković and Milena Popov at different programs of Interdisciplinary Studies, and Valentina Radoman, at the Academy of Arts in Novi Sad (see Table 1). A closer look at the subjects and areas of interest of her students, reveals that the primary goal of a professor's career - to educate young generations and provide them with an institutional space for their research - was fulfilled in the case of Vesna Mikić's work. It is obvious that she encouraged an interdisciplinary understanding of music, and also enabled the widening of 'musicological interests' through working with students. Among the titles of the papers, we find those dedicated to neoclassicism in Serbia/Yugoslavia and other European countries (mainly France), contemporary Serbian composers, the institutional understanding of music, popular, electroacoustic and film music, as well as issues of identity, language, performance studies, media, music and (bio)politics, etc. - in other words, the majority of papers were focused on areas and theories that were (and are) topical in the world of theory and of the humanities. As for her work with

13 For example, she also coordinated a course named "Aspects of $20^{\text {th }}$ Century Music", an electoral subject for PhD students at the Faculty of Music in Belgrade. This course did not only explain details about the music of the given period, but also gave the students the opportunity to work on creating a project proposal with all its details - expenses, detailed plans, projections of its impact - details that do not pertain to the traditionally perceived work of musicians. 
'musicological youth', it is important to note that, in 2019, four $\mathrm{PhD}$ theses whose proposals were accepted by the relevant academic bodies, were being written under her mentorship (see Table 4).

I have already mentioned the unique relationship with students that was typical of Professor Mikić. In a way, her entire approach to teaching and working with students, was that of a mentor. She was always aware of the importance of working with younger generations and those whose time is yet to come, and always emphasised the fact that, whether one does it intentionally or not, professors teach their students much more than (just) what is in the syllabus. As her career progressed, Professor Mikić became increasingly certain that nurturing the future of musicology and music ('materialised' in the form of students), is just as important as one's musicological and scientific research. Thus, even though her research inevitably informed and governed her activities as a professor, the reverse influence was very visible as well working with students marked her scientific research, especially in the later years. One written proof of this relationship can be found in her book Faces of Serbian Music: Neoclassicism, ${ }^{14}$ which is also dedicated "To my students, with whom I was lucky to work". In the foreword to the book, she wrote that the publication was a result of her continued research of French Neoclassicism, but also of her work with students, to whom she attempted to explain the intricate features of this music and time period. One of the reasons for writing the book was, as she says, "the fact that some students had a hard time understanding Neoclassicism", and adds:

Fortunate circumstances, by which I primarily mean the cleverness, broad education and freedom in communication of students I had the pleasure to teach, as well as the ever-growing accessibility of publications and other forms of acquiring knowledge, brought me at this time, to the solution I'm offering to readers and younger generations. ${ }^{15}$

Thus, the book, often used as a kind of textbook for Neoclassicism, as well as the numerous guises it takes in the context of Serbian and Yugoslav artistic music, is not only a result of Professor Mikić's wish to explain the subject at hand to students, but is a text whose final form came from a special kind of 'collaboration' between students and the author, and her readiness to listen to them, learn from them and use the knowledge she acquired in her future work.

14 Vesna Mikić, Lica srpske muzike - neoklasicizam (Faces of Serbian Music: Neoclassicism), Beograd, Fakultet muzičke umetnosti, Katedra za muzikologiju, 2009.

15 Ibid., 5 
Similar sentiments are present in an interview, recorded in 2018, as part of the celebration of the $70^{\text {th }}$ anniversary of the Department of Musicology. In the video, she explains her understanding of the studies of musicology, showing (us) once more the pleasure she takes from working with the younger generations:

Studies of Musicology should represent an oasis in a world that is never simple [...]. I believe that such an oasis can be very significant for every young person. On the other hand, we can offer our students a broad education [...]. One thing I can promise to everyone who is interested - is great fun. For me, even today, the most important thing is to have fun while I do my job, and I can say that I was lucky to get such a position [...], and to still have crazy fun studying musicology. ${ }^{16}$

The quoted segment of the interview reveals a number of aspects of Vesna Mikić's (professional) personality, as well as personal and ethical beliefs she wholeheartedly tried to 'transfer' to her students. First of all, we can notice her unique form of address, and approach to work, which she herself labeled as 'semi-serious', or 'semi-formal' earlier in the interview, and her need to always find something funny and interesting about her job that she would enjoy. Such an approach never implied a lack of responsibility or an understanding that one's work is not important if it is fun - on the contrary, Professor Mikić believed that a serious approach to one's profession is best taught and learnt when a 'serious' approach is not equated with being rigid or 'strict'. Such an approach to her profession was mirrored in her relationship with the students as well, as her communication with us was open, sincere and fun, and often crossed the boundaries of the traditional, strict, professor-student relationship. Her concern for the students she worked with, obvious in her wish to 'protect them from the world', as she implies in the quoted interview, also often resulted in her readiness and willingness to, at least for a moment, leave the role of the professor and 'become' a friend, advice-giver, a person of trust - showing her students that she was always 'on their side'.

Another telling aspect of the afore-mentioned interview was the final sentence, as she explained that she always wanted to have fun 'studying musicology' - by (purposefully) formulating the sentence in such a way, she revealed that she viewed learning as a perpetual process, and that she was

16 "Vesna Mikić - O studiranju muzikologije i profesionalnom radu”, 5. 9. 2018. https://www.youtube.com/watch?v=uufqyH0fkp8. Given here is my free translation of the interview. 
always learning while teaching, studying music/musicology, and growing together with her students.

If I were to summarise Vesna Mikićs work as a professor at this point, I would have to reiterate a number of features that define her as a teacher, but also as a person. For one, her need to structure her lessons in a way that is interesting, informative and dynamic, enabled her to formulate a unique lecturing style that was appreciated by many students. She always attempted to make the knowledge she gave useful, and to help her students learn skills that would enable them to function more easily in the (local) world of music, as she was always aware that they would one day inevitably leave the 'oasis' offered by university life. Attaching great importance to her pedagogical work, she always insisted on the work with students being inseparable from her musicological research, and these two areas were deeply intertwined throughout her career. Thus, she always strived to use her institutional position - with which came great responsibility she was always aware of - in order to help younger generations grow and become conscious, responsible professionals. Her professional career was marked by 'adherence' to the basic scientific principles of the constant questioning of everything we think we know, and perpetual learning, which is what she always endeavoured (and succeeded) to teach her students. 
Table 1: PhD and master's theses defended under the mentorship of Vesna Mikić17

\begin{tabular}{|l|l|}
\hline Student & Title \\
\hline Milena Popov & $\begin{array}{l}\text { "Relationship Between Biopolitics and Ecoaesthetics in Theories of Art And } \\
\text { Media", PhD thesis, University of Arts in Belgrade, Interdisciplinary studies, } \\
\text { co-mentor: Miško Šuvaković, PhD, 2013. }\end{array}$ \\
\hline Biljana Leković & $\begin{array}{l}\text { "Critical Musicological Research of The Arts of Sound: Music and Sound Art", } \\
\text { PhD thesis Faculty of Music in Belgrade, 2015. }\end{array}$ \\
\hline Iva Simčić & $\begin{array}{l}\text { "Collectivism as a strategy of art resistance: politicality of painting after the } \\
\text { 2060" PhD thesis, University of Arts in Belgrade, Interdisciplinary studies, }\end{array}$ \\
\hline Smilika Jovanović & $\begin{array}{l}\text { "Issues of Theoretical Appropriation: Carnival and Masquerade in Culture, } \\
\text { Arts, and Theory", PhD thesis, University of Arts in Belgrade, Interdisciplin- } \\
\text { ary studies, 2016. }\end{array}$ \\
\hline $\begin{array}{l}\text { Jelena Mihajlović } \\
\text { Marković }\end{array}$ & $\begin{array}{l}\text { "Modes of organization of Sergei Prokofiev's tonal system", PhD thesis, Uni- } \\
\text { versity of Arts in Belgrade, Interdisciplinary studies, 2016. }\end{array}$ \\
\hline $\begin{array}{l}\text { Valentina } \\
\text { Radoman }\end{array}$ & $\begin{array}{l}\text { "Functions of Ideology and Politics in Music Modernism", PhD thesis, Acad- } \\
\text { emy of Arts, University of Novi Sad, 2016. }\end{array}$ \\
\hline Milan Milojković & $\begin{array}{l}\text { "Digital technology in Serbian artistic musical output (1972-2010), PhD } \\
\text { thesis Faculty of Music in Belgrade, 2018. }\end{array}$ \\
\hline $\begin{array}{l}\text { Valentina } \\
\text { Radoman }\end{array}$ & $\begin{array}{l}\text { "Elements of the Impressionist Style in Serbian Music of the First Half of the } \\
\text { 20th century", master's thesis, Faculty of Music in Belgrade, 2006. }\end{array}$ \\
\hline Asja Radonjić & $\begin{array}{l}\text { "Promotion and Diffusion of Serbian Artistic Music as a Key Element of } \\
\text { Dojčinović, University of Arts in Belgrade, Interdisciplinary studies. }\end{array}$ \\
\hline Tijana Paunković & $\begin{array}{l}\text { "Media Analyses of Art by Red Hot Chili Peppers", master's thesis, University } \\
\text { of Arts in Belgrade, Interdisciplinary studies, 2008. }\end{array}$ \\
\hline
\end{tabular}

17 The information available in the following tables was taken from documents from Vesna Mikićs personal archive, as well as from the records about defended theses, made available to me by the staff of the Faculty of Music in Belgrade, to whom I am very grateful. 
Table 2: Graduation theses, defended under the mentorship of Vesna Mikić18

\begin{tabular}{|c|c|}
\hline Jasna Ristovska & "Citations in the Opus of Dejan Despić", Faculty of Music, Belgrade, 2003. \\
\hline Branka Popović & $\begin{array}{l}\text { "Closeness of Creative Poetics of Igor Stravinsky and Pablo Picasso, in Light } \\
\text { of Modernist Overturn in Art", Faculty of Music, Belgrade, } 2003 .\end{array}$ \\
\hline Damir Rondić & $\begin{array}{l}\text { "Postmodernist Coordinates of Žarko Mirkovićs poetics", Academy of Arts, } \\
\text { University of Novi Sad, } 2006 .\end{array}$ \\
\hline Milica Doroški & $\begin{array}{l}\text { "Artistic Output of Erno Kiraly in the Context of 'New Art Practice' in Vojvo- } \\
\text { dina" Academy of Arts, University of Novi Sad, } 2007 .\end{array}$ \\
\hline Jelena Đorđević & $\begin{array}{l}\text { "Treatment of Quotes in Works by Milan Mihajlović" Faculty of Music, Bel- } \\
\text { grade, } 2007 .\end{array}$ \\
\hline Marija Nikolić & $\begin{array}{l}\text { "Images of Chaos by Zoran Erić: the edge of chaos as a source for artistic creativ- } \\
\text { ity", Faculty of Music, Belgrade, } 2007 .\end{array}$ \\
\hline Maja Vasiljević & $\begin{array}{l}\text { "Institutional frame for the affirmation of composers of music for film/film } \\
\text { music in SFRY (1960-1975)", Faculty of Music, Belgrade, } 2007 .\end{array}$ \\
\hline Sanja Kunjadić & $\begin{array}{l}\text { "Salvatore Sciarino: Luci miei traditrici. Problems of Contemporary Opera or } \\
\text { Le Ferite del Tempo", Faculty of Music, Belgrade, } 2007 .\end{array}$ \\
\hline Jelena Arnautović & $\begin{array}{l}\text { "Popular Music at Radio Belgrade (1945-1990): Between Politics and the Mar- } \\
\text { ket", Faculty of Music, Belgrade, } 2008 .\end{array}$ \\
\hline Biljana Srećković & $\begin{array}{l}\text { "Modernist Project of Pierre Schaffer - from Radiophony Towards Musical Re- } \\
\text { search", Faculty of Music, Belgrade, } 2008 .\end{array}$ \\
\hline Nataša Turnić & $\begin{array}{l}\text { "Eric Satie’s Theater: Life as Theater and Early Music for the Stage (1891 - } \\
\text { 1914)", Faculty of Music, Belgrade, } 2008 .\end{array}$ \\
\hline $\begin{array}{l}\text { Smiljka } \\
\text { Milosavljević }\end{array}$ & "Identity Positionings of John Zorn", Faculty of Music, Belgrade, 2009. \\
\hline Mirjana Veličković & $\begin{array}{l}\text { "Opus of Miloš Petrović in the Context of Postmodernism and Crisis of Na- } \\
\text { tional Identity", Faculty of Music, Belgrade, } 2010 .\end{array}$ \\
\hline Stefan Cvetković & "Pianism in the Modernist Epoch", Faculty of Music, Belgrade, 2010. \\
\hline Damjana Njegić & $\begin{array}{l}\text { "Music Outside the 'Ideal Musical Culture': Case Studies - Opus of } \\
\text { W.A.Mozart", Faculty of Music, Belgrade, } 2010 .\end{array}$ \\
\hline Mina Mijušković & $\begin{array}{l}\text { "Kurt Weil and The Threepenny Opera in the Context of the Weimar Republic", } \\
\text { Faculty of Music, Belgrade, } 2011 .\end{array}$ \\
\hline Jelena Petrović & "Music in Dark Wave Films", Faculty of Music, Belgrade, 2012. \\
\hline
\end{tabular}

18 Titles of papers in Tables 2, 3 and 4 are originally in Serbian, and were translated by the author of this text, for orientation purposes. 


\begin{tabular}{|l|l|}
\hline Jelena Jovanović & $\begin{array}{l}\text { "Functionality of Music by Boris Tamindžić: The Issue of Sounding Images and } \\
\text { Movement in Beštije by Jovan Lukin and Čudo neviđeno by Živko Nikolić", Fac- } \\
\text { ulty of Music, Belgrade, 2012. }\end{array}$ \\
\hline Vojana Vrtikapa & $\begin{array}{l}\text { "Music as Event, Music as Life - Viewing Fluxus from the Viewpoint of Musi- } \\
\text { cology/Music", Faculty of Music, Belgrade, 2013. }\end{array}$ \\
\hline $\begin{array}{l}\text { Dušanka Jelenković } \\
\text { Vidović }\end{array}$ & $\begin{array}{l}\text { "Nostalgia and the Opera Breasts of Tiresias by Francis Poulenc", Faculty of } \\
\text { Music, Belgrade, 2013. }\end{array}$ \\
\hline Vladanka Malešić & $\begin{array}{l}\text { "Female Sexuality in Hindemith's Opera Trilogy", Faculty of Music, Belgrade, } \\
2016 .\end{array}$ \\
\hline
\end{tabular}

Table 3: Master theses defended under the mentorship of Vesna Mikić

\begin{tabular}{|c|c|}
\hline Ivan Malić & $\begin{array}{l}\text { "New Program Orientation of Belgrade String Orchestra 'Dušan Skovran’: Imple- } \\
\text { mentation of Adaptable Quality Management in Circumstances of Transition”, Uni- } \\
\text { versity of Arts in Belgrade, Interdisciplinary Studies, } 2010 .\end{array}$ \\
\hline Milan Milojković & $\begin{array}{l}\text { "Analyses of Language of Musicology as a Discipline in the Field of Theory (Serbia } \\
\text { 1945-1980) - a Contribution to Musicological-Theoretical Practice", Faculty of } \\
\text { Music, Belgrade, 2011. }\end{array}$ \\
\hline Jelena Gudović & $\begin{array}{l}\text { "Popular Music Within the Musicological Discourse", Faculty of Music, Belgrade, } \\
2011 .\end{array}$ \\
\hline Milica Mitić & $\begin{array}{l}\text { "Promotion of Unestablished Music Authors in the Youth Cultural Centers. Case } \\
\text { Study: Cultural Center Rex", University of Arts in Belgrade, Interdisciplinary Studies, } \\
2013 .\end{array}$ \\
\hline Adriana Sabo & $\begin{array}{l}\text { "International Review of Female Composers? A possible Outlook on the Position of } \\
\text { Female Composers Within the Local Musical Scene", Faculty of Music, Belgrade, } \\
\text { 2012. }\end{array}$ \\
\hline Tamara Kojić & $\begin{array}{l}\text { "Tradition and Past from the Standpoint of Moderate Postmodernism in the Late } \\
\text { Vocal-Instrumental Pieces by Rajko Maksimović", Faculty of Music, Belgrade, } 2012 .\end{array}$ \\
\hline Jelena Damjanović & $\begin{array}{l}\text { "Relationship of Traditional and Electronic Media in the Output of Serbian Compos- } \\
\text { ers of Electroacoustic Music, Vladan Radovanović, Srđan Hofman and Jasna } \\
\text { Velićković", Faculty of Music, Belgrade, } 2012 .\end{array}$ \\
\hline Nenad Đurđević & $\begin{array}{l}\text { "Poetic Frameworks of the Artistic Practice of Ivo Pogorelić (With Special Attention } \\
\text { Given to the Role of Belgrade-Based Media in their Reception), Faculty of Music, } \\
\text { Belgrade,2012. }\end{array}$ \\
\hline Vanja Spasić & $\begin{array}{l}\text { "After the 'Golden Age' - Opera of Serbian National Theater in Belgrade (1971- } \\
\text { 2011)", Faculty of Music, Belgrade, } 2013 .\end{array}$ \\
\hline Marija Maglov & $\begin{array}{l}\text { "Serious Music on Records Published by PGP RTB/PGPRTS (1968-1994)", Faculty of } \\
\text { Music, Belgrade, } 2013 .\end{array}$ \\
\hline Albuna Krecu & $\begin{array}{l}\text { "George Enescu and the Establishment of Romanian Musical Modernism", Faculty of } \\
\text { Music, Belgrade, } 2013 .\end{array}$ \\
\hline
\end{tabular}




\begin{tabular}{|l|l|}
\hline $\begin{array}{l}\text { Aleksandra } \\
\text { Jovanović }\end{array}$ & $\begin{array}{l}\text { "Postmodernist Play of Transformation of Identity Positions in the Opera 'Two Girls } \\
\text { and a Head' by Isidora Žebeljan”, Faculty of Music, Belgrade, 2015 }\end{array}$ \\
\hline $\begin{array}{l}\text { Bojana } \\
\text { Radovanović }\end{array}$ & $\begin{array}{l}\text { “'Science as Art' - Interdisciplinarity in Scientific Papers by Dragutin Gostuški”, Fac- } \\
\text { ulty of Music, Belgrade, 2015. }\end{array}$ \\
\hline Ana Đorđević & $\begin{array}{l}\text { "Music for Seven Offensives: Musical Conventions in Partisan Film Spectacles", Fac- } \\
\text { ulty of Music, Belgrade, 2016. }\end{array}$ \\
\hline Maša Spaić & $\begin{array}{l}\text { "Casella's 'Third Way': Alfredo Casella - Relationship Towards Modernism and the } \\
\text { Fascist Regime”, Faculty of Music, Belgrade, 2016. }\end{array}$ \\
\hline Jovana Avramović & $\begin{array}{l}\text { "Post-war Music for Children in Serbia - from Musical Upbringing of Pioneers to } \\
\text { the 'Joy of Europe' Festival, to the Children's TV show 'Na slovo, na slovo", Faculty of } \\
\text { Music, Belgrade, 2017. }\end{array}$ \\
\hline
\end{tabular}

Table 4: PhD theses whose proposals were accepted by the bodies of the Faculty and University, written under the mentorship of Vesna Mikić

\begin{tabular}{|l|l|}
\hline $\begin{array}{l}\text { Nataša Turnić } \\
\text { Đorđić }\end{array}$ & $\begin{array}{l}\text { "Outside and In Between: Eric Satie and the Art of Provocation", Faculty of Music, } \\
\text { Belgrade, Department of Musicology, proposal accepted in 2011. }\end{array}$ \\
\hline Marija Maglov & $\begin{array}{l}\text { "Media Turnover in Music: Production and Reception of Music in the Context of } \\
\text { Media Culture of the } 20^{\text {th }} \text { Century", Faculty of Music, Belgrade, Department of Mu- } \\
\text { sicology, proposal accepted in 2017. }\end{array}$ \\
\hline Adriana Sabo & $\begin{array}{l}\text { "Performativity of Gender and Music in Serbia after 1989", Faculty of Music, Bel- } \\
\text { grade, Department of Musicology, proposal accepted in 2017. }\end{array}$ \\
\hline $\begin{array}{l}\text { Bojana } \\
\text { Radovanović }\end{array}$ & $\begin{array}{l}\text { "The Voice and Technique/Technology in Contemporary Music", Faculty of Music, } \\
\text { Belgrade, Department of Musicology, proposal accepted in 2019. }\end{array}$ \\
\hline
\end{tabular}

\section{Works Cited}

Mikić, Vesna: Lica srpske muzike - neoklasicizam. Beograd: Fakultet muzičke umetnost, Katedra za muzikologiju, 2009.

Mikić, Vesna: Muzika u tehnokulturi. Beograd: Univerzitet umetnosti, 2004.

Miladinović Prica, Ivana: "Virtual Round-Table to Mark the 70th Anniversary of the Department of Musicology at The Faculty of Music in Belgrade (Vesna Mikić, Leon Stefanija, Ivana Perković, Dario Martinelli)”, New Sound, 52, II/2018, 19-33.

Радовановић, Бојана: „Музикологија 21. века? Теме и приступи дипломских и мастер радова студената београдске школе музикологије“, ТРАДИЦИЈА КАО ИНСПИРАЦИЈА, Тематски зборник са научног скупа 2017. године, Бања Лука, Академија умјетности Универзитета у Бањој Луци, Академија наука и умјетности Републике Српске, Музиколошко друштво Републике Српске, 2019, 397-416. 


\section{Internet and archival sources}

Jean Monnet Module "Musical Identities and European Perspective: An Interdisciplinary Approach", https://www.midep.ac.rs/

Jean Monnet Module "Music and Art in the Shaping of the European Cultural Identity", http://arte.bg.ac.rs/

Center for Popular Music Research, Belgrade, www.cepom.org

Musicology Department FMA Belgrade, "Vesna Mikić - O studiranju muzikologije i profesionalnom radu", 5.9.2018, https://www.youtube.com/watch?v=uufqyH0fkp8

Composers' Association of Serbia, "Seminar o popularnoj muzici”, 2013. http://composers.rs/?p=3107

Весна Микић, „Образац 2“, unpublished, personal archive.

Records of defended graduation and master theses, Faculty of Music, Belgrade.

\section{Summary}

This text is dedicated to the pedagogical activity of Professor Vesna Mikić, who held the position of Full Professor at the Department of Musicology, Faculty of Music in Belgrade. As this position dictates, her professional career was marked by both scientific and pedagogical work, which, naturally, overlapped and complemented one another. As a professor, she was very popular among students and she constantly strived to make her lectures both interesting and useful. Given that her field of research mostly revolved around contemporary, electroacoustic, popular and film music, she dedicated most of her career as a professor to disseminating this knowledge among the members of the younger generations, broadening musicology's field of study and constantly questioning its limits. She was also well-known for a great number of mentorships - many students who were interested in different forms of contemporary music, chose her as a mentor, not just for her expertise in the field, but also because of her friendly and energetic personality and openness towards new ideas and different opinions. By examining the structure of the courses she gave lectures in, as well as by quoting her own statements about the students she worked with, this paper aims at presenting some constants that marked her approach to teaching and to musicology as well. 
Чланак примљен 11. маја 2020.

Чланак прихваћен 5. јуна 2020.

Оригинални научни рад

\begin{abstract}
Адриана Сабо *
Истраживач-приправник, докторанд

Катедра за музикологију, Факултет музичке уметности

Универзитет уметности у Београду
\end{abstract}

\title{
ПЕДАГОШКА ДЕЛАТНОСТ ВЕСНЕ МИКИЋ
}

\begin{abstract}
Апстракт: Овај текст разматра професорски рад др Весне Микић (1967-2019), редовног професора на Катедри за музикологију Факултета музичке уметности у Београду. Како је највећи део своје професионалне каријере везала управо за ову институцију, у раду ће бити представљени курикулуми предмета које је током година предавала, те расветљен начин на који је са студентима обрађивала различите теме и историјске периоде. Кроз преглед њених активности као професора и ментора дипломских и мастер радова, као и докторских дисертација, настојаћу да укажем на својеврсну црвену нит (односно нити) која је повезивала различите аспекте њеног професионалног деловања у локалном свету музике.
\end{abstract}

Кључне речи: Весна Микић, музикологија, Факултет музичке уметности, педагошки рад, историја музике, популарна музика, електроакустичка музика

Када су у питању професионалне, музиколошке активности др Весне Микић, оне су протицале у два, међусобно неодвојива тока која су дефинисала научни и педагошки рад. Сасвим природно, ова два аспекта деловања су произашла из њеног рада на Катедри за музикологију Факултета музичке уметности у Београду, међусобно се употпуњујући и повезујући. Овај текст ће, имајући у виду наведену вишеструкост њених деловања, бити посвећен пре свега педагошком сегменту рада др Весне Микић који је са годинама, чини се, непрестано добијао на важности. Институционална позиција коју је имала, а која је подразумевала истовремени рад на истраживањима у области музикологије, али и бригу о (научном) подмлатку који ће бити образован управо на темељу таквих истраживања, резултирала је врло разгранатом делатношћу ове музиколошкиње, на чији професионални рад је сарадња са младима оставила дубок траг. Имајући то у виду, осврнућу се на курсеве које је осмишљавала и предавала, њихову структуру и значај за локалну музичку заједницу, као и на њен приступ раду са студентима, и важност коју је придавала овом сегменту свог посла.

\footnotetext{
* Ауторкина контакт адреса: adrianasabo259@gmail.com
} 
Поред рада на Катедри за музикологију Факултета музичке уметности у Београду, ${ }^{1}$ била је, у различитим периодима, активна и као предавач на Факултету уметности у Приштини, Музичкој академији на Цетињу, Филозофско-уметничком факултету у Крагујевцу, Академији уметности у Новом Саду, у оквиру Интердисциплинарних докторских студија Универзитета уметности у Београду (Група за теорију уметности и медија, Група за дигиталну уметност, Група за вишемедијску уметност), те на Академији Ујметности Универзитета у Бањој Луци. Предавала је махом предмете који су се тицали уметничке музике XX и XXI првог века (пре свега, музике у Југославији и неокласицизма), те курсеве посвећене различитим облицима медијски посредоване музике, попут популарне, електронске/електроакустичке музике, филмске музике, музике за телевизију итд. Осим по темама којима се бавила и проблемским круговима које је својим истраживањима отварала, многима ће остати у сећању и по непосредном и срдачном односу са колегама и студентима, енергичним предавањима и способности да оживи и сликовито дочара проблеме које је на предавањима тумачила, везујући их увек за савремени тренутак у коме живимо.

Важан део њене предавачке делатности, био је везан за предмете посвећене историји локалне, као и европске класичне музике XX века, а које је предавала студентима завршне године студија музикологије у оквиру главних предмета, али и студентима других одсека Факултета, на курсевима такозване упоредне историје музике. ${ }^{2}$ Једна од особености начина на који је Весна Микић конципирала курсеве које је предавала, било је сагледавање музике у контексту, односно инсистирање на разумевању музике као друштвеног феномена који је увек зависан од политичких, економских и идеолошких промена и превирања. У том смислу, њена предавања су проблематизовала политичке аспекте (класичне) музике, сагледавајући актере музичких догађаја у светлу бурних друштвених догађаја који су обележили историју Европе у, пре свега, XX веку. Попут њених научних истраживања, и курсеви које је предавала су били осмишљени интер- односно трансдисциплинарно, ${ }^{3}$ са подразумеваним фокусом на музици и њеним особеностима. Инсистирањем на контекстуализацији музике и размишљању о њој на начин који је не посматра као аутономну уметност, проф. Весна Микић је настојала да својим студентима укаже и на разлоге због којих је важно учити историју, увек наглашавајући да се она мора изучавати пре свега како бисмо могли да разумемо сопствену садашњост. У том смислу, увек је

\footnotetext{
${ }^{1}$ На овој институцији, запослена је као асистент 1992. године, а у звање редовног професора изабрана 2015. године.

2 У питању су, између осталог, курсеви који су део студијског програма Музикологија, и припадају сегменту означеном као Општа историја музике - Савремена, и Национална историја музике - Савремена, те Историја музике 5 и 6, посвећене музици XX века, а намењеној студентима извођачких и других научних одсека.

3 О значају таквог приступа музици, Весна Микић каже да јој је својеврсно „постмодернистичко интензивирање музике у контексту“ темељно дефинисало њен педагошки рад. Како каже, „као музиколог и предавач представим и предајем неке нове предмете [...] у оквиру курикулума факултета на коме радим, већ и да, током готово једне деценије, предајем и обликујем предавања у оквиру интердисциплинарних постдипломских студија Универзитета уметности у Београду“. Ivana Miladinović Prica, „Virtual Round-Table to Mark the 70th Anniversary of the Department of Musicology at The Faculty of Music in Belgrade (Vesna Mikić, Leon Stefanija, Ivana Perković, Dario Martinelli)“, New Sound 52, II/2018, 25.
} 
истицала својеврсну „употребну вредност“ часова историје музике, како би помогла извођачима и/или композиторима да осмисле своје поетике у односу на актуелни друштвени тренутак, односно подстакла студенте наука о музичкој уметности да размишљају о разлозима због којих своја истраживања усмеравају на одређени период/ствараоца, те да увек одреде позицију из које говоре, и своју агенду. Инсистирајући на чињеници да смо сви део света музике у Србији, али и ширег друштва, указивала је на важност и тежину сваке написане или изговорене речи, скрећући пажњу да је потребно, не само стати иза онога што је написано/речено, већ имати у виду и барем неке од потенцијалних последица својих ставова.

Поред обавезних и главних предмета које је предавала на Факултету музичке уметности у Београду, а који су се тицали историје музике, Весна Микић је важан допринос ширењу како области музиколошких истраживања, тако и знања која се студентима на Факултету нуде, дала и кроз изборне предмете посвећене електроакустичкој, популарној (Теорије популарне музике и уметности /2005/, Популарна музика 1 - теорије /2009/ и Популарна музика 2 - жанрови /2012/, Историја популарне музике 1 и 2) и филмској музици. Својим научним и истраживачким, али и педагошким радом, дакле, Весна Микић је дала важан допринос преиспитивању граница и оквира музиколошке дисциплине, односно својеврсном проширивању поља и сфере интересовања музикологије. Могло би се, тако, рећи да су области којима се бавила, те курсеви које је осмишљавала, били усмерени на (како слови наслов њене докторске дисертације ${ }^{4}$ ),музику у технокултури“, односно различите појавне облике које задобија музика у друштвима којима доминирају технологија и медији. У том смислу, В. Микић је у великој мери допринела институционализацији области истраживања која се, до пре неколико деценија, нису сматрала традиционално музиколошким. Иако електроакустичка музика свакако јесте део курикулума предмета посвећених разумевању савремене музике, важно је нагласити да је у оквиру предмета Електроакустичка музика који је водила, студентима омогућено детаљније фокусирање на музику која се не изводи на традиционалним музичким инструментима, односно на питања употребе различитих технологија у музици и њихов утицај на ову уметност, те потенцијално ширење области студија електроакустичке музике. У том смислу, овај курс је нудио и знања која се тичу технолошког аспекта ове музике, а која су се тицала и упознавања са уређајима који се користе приликом стварања електроакустичке музике синтетизерима звука, рачунарима, софтверима итд., те разумевања процедура и начина на који се у музици користе (кроз стицање знања о аналогној и дигиталној технологији, синтези, употреби ефеката, филтера итд.), ступајући на тај начин и у домен инжењерске струке, наравно, у оној мери у којој је то за студенте музике било неопходно.

Подједнако важна, јесу и „отварања“ студија музике ка истраживањима популарне музике и културе, те музичке индустрије. Иако популарна култура и музика јесу предмет истраживања музикологији сродних дисциплина, попут студија културе, социологије, студија медија итд., њихово сагледавање из угла музикологије није било нарочито

\footnotetext{
${ }^{4}$ Vesna Mikić, Muzika u tehnokulturi, Beograd, Univerzitet umetnosti, 2004.
} 
заступљено у локалној средини до пре око две деценије, а кључан допринос институционализацији ових знања, дали су управо предмети посвећени популарној музици, које је похађао великі број студената музикологије, али и других одсека Факултета музичке уметности. Будући да су за свако истраживање популарне музике нужни свест о њеном месту у друштву, разумевање тржишне логике, начина на који функционише музичка индустрија, као и разумевање суштинског места које технологија заузима у њеној производњи, дисеминацији и рецепцији, курсеви посвећени овој теми омогућавали су студентима и увид у шира и комплекснија друштвена питања која, само наизглед, стоје „изван“ музике. У намери да институционализује студије популарне музике и створи простор млађим истраживачима чија су се интересовања тицала ове области, професорка Микић је основала и Центар за истраживање популарне музике, ${ }^{5}$ чији су сарадници бивши и садашњи студенти, пре свега музикологије, али и других музичких дисциплина. ${ }^{6}$ На тај начин, настојала је и да подстакне даљу едукацију младих у истраживању ових области, те да формира и скуп музиколошких знања која се тичу популарне музике и културе.

Разматрања повезаности популарне културе и музике са политиком, технологијом и медијима, на посебан начин је презентовано у оквиру курса „INSIEME - UNITE, UNITE EUROPE! - Увод у контекстуалне студије фестивала Песма Евровизије“, а који је у периоду од 2014. до 2017. године био део Жан Моне модула (Jean Monnet Module) „Музички

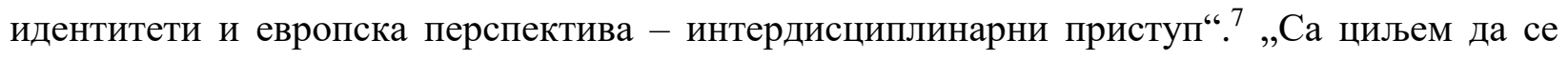
реализује јединствени музиколошки приступ сагледавању такмичења за Песму Евровизије у контексту европских студија“, наведено је на интернет презентацији модула, у оквиру курса су комбиноване вештине др Весне Микић „у преношењу знања из области популарне културе, као и искуство стечено учествовањем у реализацији пројекта ЕСЦ и Нова Eвропа“. 8 У оквиру овог курса, дакле, тумачен је врло сложени феномен такмичења за Песму Евровизије, а за чије разумевање су потребна знања која се тичу медија, технологије, политике, идентитета, музике - дакле, свих оних области иначе обухваћених предметима које је Весна Микић предавала. Са сличном намером формирања музиколошког приступа истраживању феномена који нису „чисто музички“, у сарадњи са доц. др Биљаном Лековић, осмишљен је и курс „Интегрисани медији, интегрисана Европа: савремена српска музика и европске (медијске) интеграције“, који се одржавао у оквиру другог Жан Моне модула, насловљеног „Музика и уметност у обликовању европског културног идентитета“.9 Циљ овог курса био је да „интегрише музиколошке интерпретације различитих савремених музиколошких пракси у савремени, интегрисани медијски диспозитив“, а у фокус постави суштинску важност медија за истраживања музике. Такође, како је даље наведено у опису

\footnotetext{
${ }^{5}$ Интернет презентација Центра за истраживање популарне музике, http://www.cepom.org/

${ }^{6}$ Сарадници Центра http://www.cepom.org/saradnici.html

7 Жан Моне модул „Музички идентитети и европска перспектива: интердисциплинарни приступ“, https://www.midep.ac.rs/.

${ }^{8}$ Весна Микић, „INSIEME - UNITE, UNITE EUROPE! - увод у контекстуалне студије фестивала Песма Евровизије“" http://www.midep.ac.rs/?page id=317\&lang=SR

9 Жан Моне модул „Музика и уметност у обликовању европског културног идентитета“, http://arte.bg.ac.rs/
} 
курса, „примена стеченог знања у теорији медија, као и европским медијским политикама и институцијама (базираним на европским интеграционим политикама) води студенте до свести о значају и функцији музике у свеукупности процеса (културних) интеграција“. 10

Треба нагласити и да је педагошка делатност др Весне Микић, осим за Факултет музичке уметности, била везана и за Интердисциплинарне докторске студије Универзитета уметности у Београду, у оквиру којих је креиран низ курсева посвећених управо интердисциплинарним истраживањима музике и већ наведеним областима. Међу курсевима који су били понуђени студентима, били су и „Теорија популарне уметности и културе“ (Група за теорију уметности и медија, од 2003. године), и „Уметност и политика“ (Група за теорију уметности и медија, Група за вишемедијску уметност, од 2010) чији је била креатор и координатор, као и курс „Нове теорије уметности/Нови медији“ (Група за теорију уметности и медија, Група за дигиталну уметност, Група за вишемедијску уметност, од 2008), чији је била координатор. ${ }^{11}$

На основу увида у курсеве које је предавала, а нарочито у структуру оних предмета чије је формирање иницирала и које је координисала - мислим, пре свега, на изборне предмете - али и захваљујући позицији студенткиње која је многе од курсева полагала, истакла бих још једну важну одлику педагошког рада проф. Весне Микић. Наиме, фокусирањем на савремене и актуелне музичке праксе, као и на проблемске кругове који се тичу места музике у животу савремених људи, настојала је да студентима понуди знања која ће их припремити за ступање на тржиште рада, али им и омогућити разумевање друштва у коме живе и, у крајњој инстанци, омогућити лакше кретање кроз живот. Настојећи да расветли начине на које функционише савремена продукција музике и знања о музици, као и да проблематизује место музике у контексту актуелних медијских култура, нудила је студентима, дакле, „употребљива знања““. ${ }^{2}$

Посебно важан аспект педагошког рада др Весне Микић, представљала су менторства на дипломским, магистарским и мастер радовима, те докторским дисертацијама, а њену каријеру обележио је и изузетно велики број менторстава. Управо су њена изузетно разграната научна делатност и широка интересовања, као и непосредан и

\footnotetext{
${ }^{10}$ Силабус курса доступан је на линку: http://arte.bg.ac.rs/wpcontent/uploads/2018/10/V.Miki\%C4\%87B.Lekovi\%C4\%87Silabus-obav.-kursSRP.pdf

11 Осим континуираног рада на формулисању курсева у оквиру високошколских установа, треба истаћи и да је Весна Микић држала и предавања отвореног типа, намењена студентима, али и широј публици. На пример, 2013. године, била је један од предавача на семинару „Популарна музика као интегрални део савремене културе“, организованом од стране Удружења композитора Србије и Факултета музичке уметности, а који је одобрио Завод за унапређење образовања и васпитања. Cf: Udruženje kompozitora Srbije, „Seminar o popularnoj muzici“, 2013. http://composers.rs/?p=3107. Поред тога, треба навести и предавање по позиву, „Serbia sounds European/Yugoslav/Balkan/global?: Popular music practices in an ever-transitional society“, одржано на Институту за музикологију Хумболдт универзитета у Берлину (2012), као и два предавања намењена студентима мастер студија музикологије Филозофског факултета у Љубљани (2013), под насловом: „Popular Music and Musicology - Interpretative Framework“ и „Production, Technology, Music Industries - Case Study: Covers“.

12 Тако је, на пример, изборни предмет понуђен студентима докторских академских студија на ФМУ, насловљен „Аспекти музике XX века“, подразумевао не само изучавање различитих музика насталих током овог столећа, већ и осмишљавање и презентацију пројекта - са формирањем трошковника, детаљног плана реализације - из области музичког стваралаштва.
} 
искрен однос са студентима, допринели да веома често буде бирана за ментора од стране, пре свега, студената музикологије, али и оних који су похађали Интердисциплинарне студије Универзитета уметности у Београду. Тако је, под менторством др Весне Микић, одбрањен 21 дипломски рад (од којих 19 на Катедри за музикологију ФМУ, а 2 на Академији уметности у Новом Саду, в. Табелу 2) и 16 мастер радова (од којих два на Универзитету уметности у Београду) (в. Табелу 3); три магистарска рада (Валентине Радоман, Асје Радоњић и Тијане Паунковић, в. Табелу 1), као и седам докторских дисертација: на Катедри за музикологију ФМУ докторирали су Биљана Лековић и Милан Милојковић, а у оквиру програма Универзитета уметности Ива Симчић, Смиљка Јовановић, Јелена Михајловић Марковић и Милена Попов, док је на Академији уметности у Новом Саду, под њеним менторством докторирала Валентина Радоман (в. Табелу 1). На основу увида у теме којима су радови посвећени, може се закључити да је педагошка активност Весне Микић испунила своју, може се рећи примарну сврху - едукацију подмлатка и формирање основа за гранање музиколошких истраживања, проширивање тематских оквира, као и прожимање музиколошких и дискурса других дисциплина. Прегледом тема радова писаних под њеним менторством, уочавају се они посвећени неокласицизму у Србији/Југославији, али и у другим европским земљама (пре свега Француској), савременим српским композиторима, институционалном сагледавању музике, популарној, електроакустичкој и филмској музици, питањима идентитета, језика, извођаштва, медијске презентације музике, музике и (био)политике итд. - другим речима, највећи део тема, фокусиран је на области и питања која су актуелна у пољу теорије и хуманистичких наука. Када је у питању неговање (музиколошког) подмлатка, треба додати и чињеницу да је, 2019. године, Весна Микић имала и четири менторства за израду докторских дисертација на Катедри за музикологију, а чији су предлози одобрени од стране одговарајућих тела Факултета и Универзитета (в. Табелу 4).

Beћ је у неколико наврата истакнут посебан однос који је Весна Микић имала према својим студентима, а у том погледу треба нагласити и чињеницу да је положај ментора - у најширем смислу те речи - обележио њен приступ раду са подмлатком. Увек свесна нужности неговања „оних који долазе“, на уму је имала чињеницу да је студенте потребно научити и вештинама које се нису нужно налазиле у оквиру силабуса, те да је педагошка активност на Факултету на коме је радила, нужно подразумевала улагање у будућност и обликовање те будућности кроз рад са онима „на којима свет остаје“. Један писани траг, који сведочи о значају који је придавала раду са студентима, може се пронаћи у књизи Лица српске музике - неокласицизам, ${ }^{13}$ иначе посвећеној, како је написала „Студентима, са којима сам имала срећу да радим“. У предговору за ову публикацију, В. Микић наводи да је она резултат њеног континуираног бављења француским неокласицизмом, али и дугогодишњег рада са студентима којима је тумачила његову проблематику. Један од повода за

13 Весна Микић, Лиц̧а српске музике - неокласицизам, Београд, Факултет музичке уметности, Катедра за музикологију, 2009. 
обликовање књиге о овој теми, била је и, како каже, „чињеница да се неки студенти нису најбоље сналазили са неокласицизмом“, и додаје:

Срећне околности, под којима пре свега подразумевам бистрину, широку образованост и слободу у комуникацији студената са којима сам имала задовољство да радим, као и све већу доступност литературе и других могућности стицања знања, у овом тренутку су ме довеле до решења које нудим читаоцима и новим генерацијама. ${ }^{14}$

Стога се може рећи да је својеврстан уџбеник коме су се генерације студената окретале у намери да разумеју, не само француски неокласицизам, већ и његове различите облике у српској музици компонованој током педесетих година прошлог века у контексту социјалистичке Југославије, настао не само из жеље да се одређена област студентима објасни, већ и као резултат 'сарадње' проф. Весне Микић и њених студената, односно њене спремности да своје студенте саслуша, и њихова размишљања прихвати и искористи у даљем раду.

У интервјуу који је дала поводом прославе 70. годишњице Катедре за музикологију, а који је забележен 2018. године, Весна Микић објашњава како види студије музикологије и шта је то што оне нуде (будућим) студентима, откривајући још једном своју наклоност према раду са младима:

[Студије музикологије треба да представљају] оазу у једном свету који није нимало једноставан (...). Мислим да та оаза може пуно да значи сваком младом човеку. С друге стране, [можемо студентима да понудимо] ширину образовања (...) која се и даље стиче на студијама. И, оно што свакако обећавам свакоме ко је заинтересован за добру забаву - то је добра забава. Мени је и дан данас најважније да се добро забављам када радим свој посао и могу да кажем да сам имала срећу да добијем такав посао (...) и да се и дан-данас лудо забављам студирајући музикологију. ${ }^{15}$

Наведене речи откривају неколико важних карактеристика (педагошке) личности Весне Микић, које се снажно трудила да пренесе и на студенте - пре свега, у питању је, како сама у истом интервјуу помиње, својеврстан „полуозбиљан“, односно пре „полуформалан“ приступ послу, у којем се увек трудила да пронађе задовољство и да га обавља са уживањем. Ипак, не може се рећи да је у послу била „неозбиљна“ већ је, управо супротно, веровала да се нужна озбиљност у приступу послу лакше учи и прихвата уколико није изједначена са ригидношћу и строгошћу. Такав однос према професији, одражавао се и на однос према студентима, са којима је увек разговарала отворено, често шаљиво и без непрестаног инсистирања на традиционалном, формалном односу професор-студент. Њена брига за студенте, очитована и у жељи да их, барем током студија, „сачува од света“, огледала се и у спремности да, макар на тренутак, искорачи из улоге професора и приближи се „функцији“ пријатеља, саветника, особе од поверења. Поред жеље да студирање и рад на Факултету учини забавним, за себе али и за друге, симптоматична је и формулација којом

\footnotetext{
${ }^{14}$ Исто, 5.

15 „Весна Микић - О студирању музикологије и професионалном раду“, 5. 9. 2018, https://www.youtube.com/watch?v=uufqyH0fkp8.
} 
завршава интервју, наводећи да се добро забавља „студирајући музикологију“. Тиме је „открила“ још један аспект приступа свом послу, а који се огледа у схватању да је учење непрекидан процес, и у спремности да од својих студената непрестано учи и са њима „расте“ кроз заједничко студирање.

Увидом у педагошку делатност ред. проф. др Весне Микић, може се закључити да су неке од кључних тачака које одликују њен рад са студентима, биле непрестана потреба да своја предавања учини разумљивим, да студентима понуди знања која ће им омогућити лакше функционисање у домаћем свету музике у тренутку када буду напустили „оазу“ коју им је омогућавало студирање, као и свест о важности бриге о научном и уметничком подмлатку. Разумевајући педагошки рад као неодвојив од научног, каријеру је посветила не само настојању да студентима пренесе знања стечена кроз истраживање различитих музичких области, већ и да своја даља истраживања усклади и са потребама студената, те своју институционалну позицију - која је носила и велику одговорност - искористи како би младима омогућила лакше „одрастање“. У истраживачком раду, као и у раду са студентима, проф. Весна Микић је увек тежила преиспитивању, темељном и критичком промишљању важних питања, а пишући о музици, настојала је да пише и мисли о (нашем) друштву, што је увек тражила и од својих студената.

Табела 1: Докторске дисертације и магистарски радови одбрањени под менторством др Весне Микић $^{16}$

\begin{tabular}{|c|c|}
\hline Студент & Наслов \\
\hline Милена Попов & $\begin{array}{c}\text { „Односи биополитике и екоестетике у теоријама уметности и медија“, } \\
\text { докторска дисертација, Универзитет уметности у Београду, } \\
\text { Интердисциплинарне студије Универзитета уметности, коментор: др Миодраг } \\
\text { Шуваковић, 2013 }\end{array}$ \\
\hline Биљана Лековић & $\begin{array}{c}\text { „Критичка музиколошка истраживања уметности звука: музика и Sound Art“, } \\
\text { докторска дисертација, ФМУ Београд, 2015. }\end{array}$ \\
\hline Ива Симчић & $\begin{array}{c}\text { „Колективизам као умјетничка стратегија отпора: политичност сликарства } \\
\text { након 1960. године“, докторска дисертација, Универзитет уметности у } \\
\text { Београду, Интердисциплинарне студије Универзитета уметности, 2016. }\end{array}$ \\
\hline Смиљка Јовановић & $\begin{array}{c}\text { „Могућности теоријске апропријације: Карневал и маскарада у култури, } \\
\text { уметнсти и теорији“, докторска дисертација, Универзитет уметности у } \\
\text { Београду, Интердисциплинарне студије Универзитета уметности, 2016. }\end{array}$ \\
\hline Јелена Михајловић \\
Марковић & $\begin{array}{c}\text { „Видови организације тоналног система Сергеја Прокофјева“, докторска } \\
\text { дисертација, Универзитет уметности у Београду, Интердисциплинарне } \\
\text { студије Универзитета уметности, 2016. }\end{array}$ \\
\hline Валентина Радоман & $\begin{array}{c}\text { „Функцие идеологије и политике у музичком модернизму“, докторска } \\
\text { дисертација, Универзитет у Новом Саду, Академија уметности, 2016. }\end{array}$ \\
\hline
\end{tabular}

16 Део података из табеле, наведен је на основу докумената из личне архиве Весне Микић. Подаци наведени у Табели 2 и Табели 3 преузети су из евиденције о одбрањеним дипломским и мастер радовима, коју су за потребе овог текста уступиле надлежне службе, којима се овом приликом срдачно захваљујем. 


\begin{tabular}{|c|c|}
\hline Милан Милојковић & $\begin{array}{c}\text { „Дигитална технологија у српском уметничком музичком стваралаштву“ } \\
\text { (1972-2010), докторска дисертација, ФМУ Београд, } 2018 .\end{array}$ \\
\hline Валентина Радоман & $\begin{array}{c}\text { „Елементи импресионистичког стила у српској музици прве половине } 20 . \\
\text { века“, магистарски рад, ФМУ Београд, } 2006 .\end{array}$ \\
\hline Асја Радоњић & $\begin{array}{c}\text { „Промоција и дифузија српске уметничке музике као кључни елементи } \\
\text { националне културне политике“, магистарски рад, Универзитет уметности у } \\
\text { Београду, Група за Менаџмент и културну политику на Балкану, } 2007 .\end{array}$ \\
\hline Тијана Паунковић & $\begin{array}{c}\text { „Медијска анализа стваралаштва групе Red Hot Chili Peppers“, магистарски } \\
\text { рад, Универзитет уметности у Београду, Група за теорију уметности и медија, } \\
2008 .\end{array}$ \\
\hline
\end{tabular}

Табела 2: Дипломски радови одбрањени под менторством др Весне Микић

\begin{tabular}{|c|c|}
\hline Јасна Ристовска & „Цитатност у опусу Дејана Деспића“, ФМУ Београд, 2003. \\
\hline Бранка Поповић & $\begin{array}{c}\text { „Блискост стваралачких поетика Игора Стравинског и Пабла Пикаса у светлу } \\
\text { модернистичког преврата у уметности“, ФМУ Београд, } 2003 .\end{array}$ \\
\hline Дамир Рондић & $\begin{array}{l}\text { „Постмодернистичке координате поетике Жарка Мирковића“, АУ Нови Сад, } \\
2006 .\end{array}$ \\
\hline Милица Дорошки & $\begin{array}{c}\text { „Стваралаштво Ернеа Кираља у контексту војвођанске Нове уметничке } \\
\text { праксе АУ Нови Сад, } 2007 .\end{array}$ \\
\hline Јелена Ђорђевић & $\begin{array}{l}\text { „Третман цитата у делима Милана Михајловића“, ФМУ Београд, } \\
2007 .\end{array}$ \\
\hline Марија Николић & $\begin{array}{l}\text { „Слике хаоса Зорана Ерића: ивица хаоса као извор уметничке креативности“, } \\
\text { ФМУ Београд, } 2007 .\end{array}$ \\
\hline Маја Васиљевић & $\begin{array}{l}\text { „Институционални оквир за афирмацију композитора музике за } \\
\text { филм/филмске музике у СФРЈ (1960-1975)“, ФМУ Београд, } 2007 .\end{array}$ \\
\hline Сања Куњадић & $\begin{array}{c}\text { „Салваторе Шарино: Luci miei traditrici. Проблеми савремене опере или Le } \\
\text { Ferite del Tempo“, ФМУ Београд, } 2007 .\end{array}$ \\
\hline Јелена Арнаутовић & $\begin{array}{c}\text { „Популарна музика на Радио Београду (1945-1990): између политике и } \\
\text { тржишта“, ФМУ Београд, } 2008 .\end{array}$ \\
\hline Биљана Срећковић & $\begin{array}{c}\text { „Модернистички пројекат Пјера Шефера - од радиофоније ка музичким } \\
\text { истраживањима“, ФМУ Београд, } 2008 .\end{array}$ \\
\hline Наташа Турнић & $\begin{array}{c}\text { „Позориште Ерика Сатија: Живот као театар и рана музика за сцену (1891- } \\
\text { 1914)“, ФМУ Београд, } 2008 .\end{array}$ \\
\hline $\begin{array}{l}\text { Смиљка } \\
\text { Милосављевић }\end{array}$ & „Идентитетска позиционирања Џона Зорна“, ФМУ Београд, 2009. \\
\hline $\begin{array}{l}\text { Мирјана } \\
\text { Величковић }\end{array}$ & $\begin{array}{c}\text { „Стваралаштво Милоша Петровића у контексту постмодерне и кризе } \\
\text { националног идентитета“, ФМУ Београд, } 2010 .\end{array}$ \\
\hline Стефан Цветковић & „Пијанизам у епохи модернизма“, ФМУ Београд, 2010. \\
\hline Дамјана Његић & $\begin{array}{c}\text { „Музика изван 'идеалне музичке културе': студије случаја - стваралаштво } \\
\text { В. А. Моцарта“, ФМУ Београд, } 2010 . \\
\end{array}$ \\
\hline
\end{tabular}




\begin{tabular}{|l|c|}
\hline Мина Мијушковић & „Курт Вајл и Опера за три гроша у контекту Вајмарске републике“, ФМУ \\
Београд, 2011.
\end{tabular}

Табела 3: Мастер радови одбрањени под менторством др Весне Микић

\begin{tabular}{|c|c|}
\hline Иван Малић & $\begin{array}{c}\text { „New program orientation of Belgrade string orchestra Dušan Skovran: } \\
\text { implementation of adaptable quality management in circumstances of transition } \\
\text { (Nova programska-organizaciona orijentacija BGO Dušan Skovran: } \\
\text { implementacija adaptivnog menadžmenta kvaliteta u uslovima tranzicije), } \\
\text { Универзитет уметности у Београду, Група за Менаџмент и културну } \\
\text { политику на Балкану, 2010. }\end{array}$ \\
\hline $\begin{array}{l}\text { Милан } \\
\text { Милојковић }\end{array}$ & $\begin{array}{c}\text { „Анализа језика музикологије као дисциплине у пољу теорије (Србија 1945- } \\
\text { 1980) - Прилог музиколошко-теоријској пракси“, ФМУ Београд , } 2011 .\end{array}$ \\
\hline Јелена Гудовић & „Популарна музика унутар музиколошког дискурса“, ФМУ Београд , 2011. \\
\hline Милица Митић & $\begin{array}{c}\text { „Promotion of unestablished music authors in the youth cultural centers. Case } \\
\text { study: Cultural Center Rex“, Универзитет уметности у Београду, Група за } \\
\text { Менаџмент и културну политику на Балкану, } 2013 . \\
\end{array}$ \\
\hline Адриана Сабо & $\begin{array}{c}\text { „Међународна трибина композиторки? Могући поглед на положај } \\
\text { композиторки у оквиру домаће музичке сцене“, ФМУ Београд, } 2012 .\end{array}$ \\
\hline Тамара Којић & $\begin{array}{c}\text { „Традиција и прошлост из визуре умереног постмодернизма у позним } \\
\text { вокално-инструменталним делима Рајка Максимовића“, ФМУ Београд, } 2012 .\end{array}$ \\
\hline Јелена Дамјановић & $\begin{array}{c}\text { „Питање односа између традиционалног и електронског медија у } \\
\text { стваралаштву српских композитора електроакустичке музике Владана } \\
\text { Радовановића, Срђана Хофмана и Јасне Величковић“, ФМУ Београд, } 2012 .\end{array}$ \\
\hline Ненад Ђурђевић & $\begin{array}{l}\text { „Поетички оквири уметничке праксе Иве Погорелића (са посебним освртом } \\
\text { на улогу београдских медија у њиховој рецепцији)“, ФМУ Београд, } 2012 .\end{array}$ \\
\hline Вања Спасић & $\begin{array}{c}\text { „После 'златног периода' - Опера Народног позоришта у Београду (1971- } \\
2011) \text { “, ФМУ Београд, } 2013 .\end{array}$ \\
\hline Марија Маглов & $\begin{array}{l}\text { „Озбиљна музика на плочама у издању ПГП РТБ/ПГП-РТС-а (1968-1994)“, } \\
\text { ФМУ Београд, } 2013 .\end{array}$ \\
\hline Албина Крецу & $\begin{array}{c}\text { Ђеорђе Енеску и формирање румунског музичког модернизма, ФМУ } \\
\text { Београд, } 2013 .\end{array}$ \\
\hline $\begin{array}{l}\text { Александра } \\
\text { Јовановић }\end{array}$ & $\begin{array}{c}\text { „Постмодернистичка игра трансформације идентитетских позиција у опери } \\
\text { 'Две главе и девојка' Исидоре Жебељан, ФМУ Београд, } 2015 .\end{array}$ \\
\hline
\end{tabular}




\begin{tabular}{|c|c|}
\hline $\begin{array}{l}\text { Бојана } \\
\text { Радовановић }\end{array}$ & $\begin{array}{c}\text { „Наука као уметност“ - интердисциплинарност у научним радовима } \\
\text { Драгутина Гостушког“, ФМУ Београд, } 2015 .\end{array}$ \\
\hline Ана Ђорђевић & $\begin{array}{c}\text { „Музика за седам офанзива: музичке конвенције у партизанским филмским } \\
\text { спектаклима“, ФМУ Београд, } 2016 .\end{array}$ \\
\hline Маша Спаић & $\begin{array}{c}\text { „Казелин 'Трећи пут’: Алфредо Казела - однос према модернизму и } \\
\text { фашистичком режиму“, ФМУ, } 2016 .\end{array}$ \\
\hline Јована Аврамовић & $\begin{array}{c}\text { „Послератна музика за децу у Србији - од музичког васпитања пионира до } \\
\text { фестивала Paдост Европе до дечије телевизијске емисије На слово, на слово, } \\
2017 .\end{array}$ \\
\hline
\end{tabular}

Табела 4: Менторства за израду докторских дисертација

\begin{tabular}{|l|c|}
\hline $\begin{array}{l}\text { Наташа Турнић } \\
\text { Ђорђић }\end{array}$ & „Изван и између: Ерик Сати и уметност провокације“, ФМУ Београд, Одсек \\
за музикологију, 2011.
\end{tabular}

\section{Цитирана дела}

Mikić, Vesna: Muzika u tehnokulturi. Beograd: Univerzitet umetnosti, 2004.

---: Lica srpske muzike - neoklasicizam. Beograd: Fakultet muzičke umetnost, Katedra za muzikologiju, 2009.

Miladinović Prica, Ivana: „Virtual Round-Table to Mark the 70th Anniversary of the Department of Musicology at The Faculty of Music in Belgrade (Vesna Mikić, Leon Stefanija, Ivana Perković, Dario Martinelli)“, New Sound, 52, II/2018, 19-33.

Радовановић, Бојана, „Музикологија 21. века? Теме и приступи дипломских и мастер радова студената београдске школе музикологије“, у: Традищија као инспирација. Тематски зборник са научног скупа 2017. године. Бања Лука: Академија умјетности Универзитета у Бањој Луци, Академија наука и умјетности Републике Српске, Музиколошко друштво Републике Српске, 2019, 397-416.

\section{Интернет презентације и архивска грађа}

Žan Mone modul „Muzički identiteti i evropska perspektiva: interdisciplinarni pristup“, https://www.midep.ac.rs/

Žan Mone modul „Muzika i umetnost u oblikovanju evropskog kulturnog identiteta“, http://arte.bg.ac.rs/

Musicology Department FMA Belgrade „Vesna Mikić - O studiranju muzikologije i profesionalnom radu“, 5.9.2018., https://www.youtube.com/watch?v=uufqyH0fkp8

Udruženje kompozitora Srbije, „Seminar o popularnoj muzici“, mart 2013. http://composers.rs/?p=3107

Centar za istraživanje popularne muzike, Beograd, www.cepom.org 
Евиденција одбрањених дипломских и мастер радова, Факултет музичке уметности у Београду, архива.

Микић, Весна: „Образац 2“, необјављено, лична архива. 